\title{
Dental schools and clinical endodontics in Brazilian Dental education institutions
}

\author{
Gustavo Machado Otto*; Camila Hélen Grock**; Francisco Montagner***
}

* DDS, Dental School, Universidade Federal do Rio Grande do Sul

** DDS, MSc, PhD, Dental School, Universidade Federal do Rio Grande do Sul

*** DDS, MSc, Ph.D., Associate Professor, Department of Conservative Dentistry, Dental School, Universidade Federal do Rio Grande do Sul

Received November 1, 2019. Approved January 4, 2020.

\begin{abstract}
This cross-sectional census study evaluated the course characteristics and clinical endodontic teaching models in Dentistry courses in Brazil. The electronic websites of 452 courses registered in the National Registry of Higher Education Courses and Institutions of the Ministry of Education were reviewed. The variables of interest were institutional data; presence of curriculum and pedagogical project of the course; course data (number of semesters, period); and data from the area of clinical endodontics. Data were entered into a database, and descriptive statistical analysis was performed. The undergraduate degree in Dentistry occurs mostly in private institutions $(86.3 \%)$ and the Southeastern region $(37.8 \%)$, with mostly daytime courses $(73.8 \%)$. The curriculum and pedagogical projects were available in $76.5 \%$ and $23.4 \%$, respectively, and were predominantly found in electronic websites of public institutions. The teaching of clinical endodontics starts in the third semester and may occur in isolate or integrated clinics. It was concluded that there is predominance of undergraduate Dental education in private institutions. There is a limited number of nighttime courses. There is a tendency for teaching of clinical endodontics to occur in association with other areas of Dentistry. The collection of information is hampered by the limited number of pedagogical projects available for consultation. Full access to those data would allow the student, upon entering the institution, to know how the teaching-learning process will take place.
\end{abstract}

Descriptors: Endodontics. Teaching. Curriculum. 


\section{INTRODUCTION}

Dental professionals should be generalist, humanistic, critical and reflective, acting at all levels of healthcare, based on technical and scientific rigor ${ }^{1}$. From data analysis of the Higher Education Census of the National Institute for Educational Studies and Research (INEP), Prats $(2005)^{2}$ indicated that there has been a great expansion of Dentistry courses in Brazil, with marked opening of new courses between the years 1996 and 2002 .

In 2013, the European Society of Endodontics (ESE) published undergraduate curriculum guidelines for endodontic education to provide information on the minimum level of competences to be achieved at the undergraduate level ${ }^{3}$. The American Association of Endodontics (AAE) published in 2017 the requirements and skills required for all dentists performing endodontics ${ }^{4}$. Currently, there is no consensus in Brazil about the organization of the curricular structure for teaching of endodontics in Dentistry courses, resulting in different approaches in quantity and distribution in curricula. Few studies in Brazil have evaluated this information. According to a study by Kappler et al. (2019) $)^{5}$, preclinical endodontic teaching activities are developed in specific disciplines and others in integrated clinical disciplines.

The National Curriculum Guidelines (2002) establish that undergraduate teaching should be based on the Pedagogical Project of each institution. This should be built collectively, centered on the student as the subject of learning for integral training and supported by the professor as facilitator and mediator of the teaching-learning process ${ }^{1}$.

Understanding how the teaching of clinical endodontics is being conducted at educational institutions may provide more accurate information on developing measures for the proper training of future Dental professionals.
Therefore, this study aimed to identify, know and analyze the available information about public or private undergraduate Dental education institutions and the teaching model in the area of endodontics.

\section{METHODS}

The study was approved by the Dental School Research Board of Universidade Federal do Rio Grande do Sul (UFRGS) (Porto Alegre, Brazil) (Protocol \#35752).

It was characterized as a cross-sectional observational census study, which consisted of consulting the 452 websites of Brazilian Dentistry courses listed in the National Registry of Higher Education Courses and Institutions, available on the website of the Ministry of Education (MEC) (http://emec.mec.gov.br/), in January 2019. All data and information collected are in the public domain. The variables of interest were institution data; presence of curriculum and pedagogical project of the course; course data (number of semesters, shifts) and data related to the area of clinical endodontics, which was categorized as "Integrated Clinical Discipline", when endodontics co-occurs with other areas, and "Clinical Endodontic Discipline" when there is a specific clinical discipline for endodontics.

After collection, data were released into a database for statistical analysis using the IBM SPSS Statistics v.21 statistical package (IBM Corp. Released 2012. IBM SPSS Statistics for Windows, Version 21.0. Armonk, NY, IBM Corp.). Descriptive analysis was performed, and data were expressed as absolute or relative frequency.

\section{RESULTS}

The websites were evaluated from 452 Brazilian undergraduate Dental courses authorized by the Ministry of Education (MEC). Over time, there has been a marked increase in new authorized and initiated courses, especially 
in private institutions, with a significant increase from 2010 (figure 1). In addition to the courses that are already in operation, 89 other courses are authorized but not yet started.

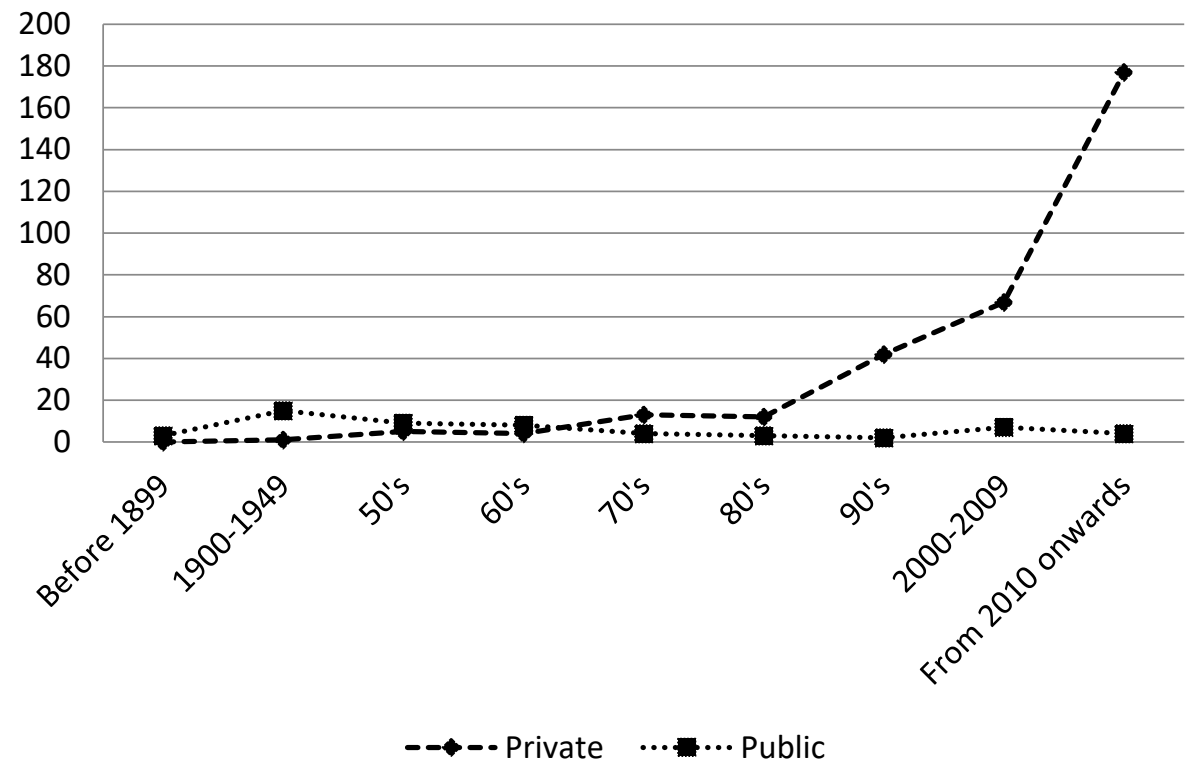

Figure 1. Numerical evolution of the start of operation of new Brazilian Dentistry courses, considering the type of maintenance institution

Among all courses surveyed, 390/452 $(86.3 \%)$ are offered at private institutions, while $62 / 452(13.7 \%)$ are offered at public institutions. Considering its distribution in the Brazilian regions, there is a higher frequency in the Southeast region with $171 / 452(37.8 \%)$, followed by the Northeast region with 121/452 (26.8\%), South 82/452 (18.1\%),
41/452 North (9.1\%) and Midwest 37/452 (8.2\%) (figure 2).

Regarding the number of vacancies, it was found that 46,326 vacancies are authorized annually for Dental courses, with $92.52 \%(42,862 / 46,326)$ offered in private institutions and only $7.48 \%$ $(3,464 / 46,326)$ in public institutions.

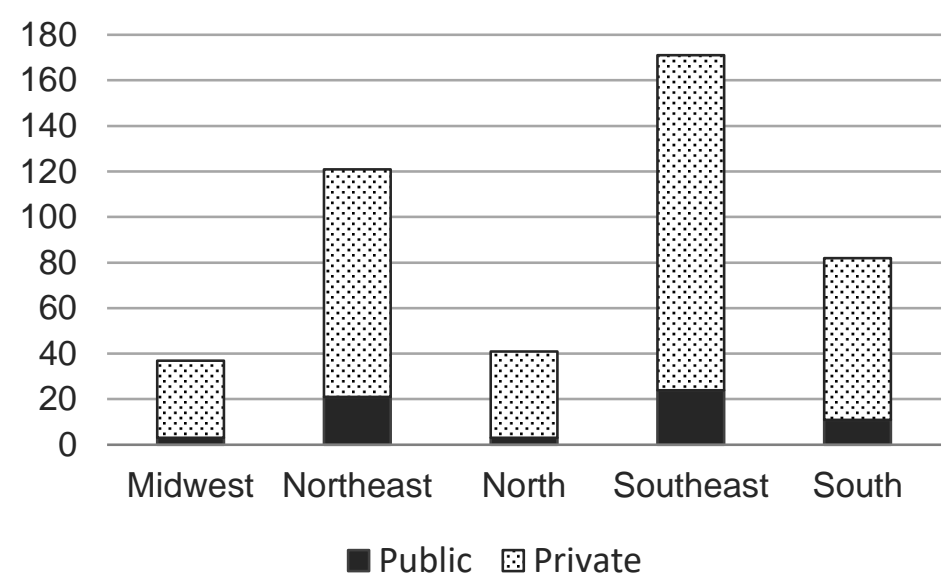

Figure 2. Number of Dentistry courses in Brazil, by region, considering the type of maintenance institution 
Information regarding the curriculum was available in $286 / 390(73.3 \%)$ of the websites of courses in private institutions and in 60/62 (96.77\%) of courses of public institutions, totaling $76.5 \%$ of the researched institutions. The availability of the pedagogical project was verified in only 67 (17.17\%) private institutions and 39 (62.9\%) courses in public institutions, resulting in only
$106 / 452(23.45 \%)$ of the institutions surveyed.

Most courses are held during the day $(334 / 452 ; 73.89 \%)$. About 21\% (95/452) are offered at nighttime; among these, $93.68 \%$ (89/95) are offered in private institutions and $6.32 \%(6 / 95)$ in public institutions. The course shift was not indicated in 23/452 (5.1\%) of evaluated courses (table 1).

Table 1. Distribution of daytime and nighttime courses in Brazilian dentistry courses by region of the country

\begin{tabular}{lcccccc}
\hline \multirow{2}{*}{ Region } & \multicolumn{3}{c}{ Public $(\mathrm{n}=62)$} & \multicolumn{3}{c}{ Private $(\mathrm{n}=390)$} \\
& Daytime & Nighttime & NI & Daytime & Nighttime & NI \\
\hline Midwest & 3 & 0 & 0 & 27 & 6 & 1 \\
Northeast & 20 & 1 & 0 & 69 & 21 & 10 \\
North & 3 & 0 & 0 & 28 & 8 & 2 \\
Southeast & 20 & 4 & 0 & 106 & 34 & 7 \\
South & 10 & 1 & 0 & 48 & 20 & 3 \\
\hline Total & 56 & 6 & 0 & 278 & 89 & 23 \\
\hline
\end{tabular}

NI: not informed

Regarding the total workload, the mean of courses was 4,406 hours, ranging from 3,780 to 6,100 hours. The total number of semesters ranged from 8 to 16 semesters, with most courses lasting 10 semesters $(336 / 452 ; 74.3 \%)$, followed by courses lasting 8 semesters $(88 / 452 ; 19.5 \%)$. In addition, $21 / 452(4.6 \%)$ courses last 9 semesters, $4 / 452(0.9 \%) 12$ semesters and 2/452 $(0.4 \%) 16$ semesters.

Among courses lasting 10 semesters $(74.3 \%)$ a total of $75.29 \%$ (253/336) provided curriculum and/or pedagogical project. Based on this information, the distribution of disciplines in the area of endodontics was evaluated.

The offer of clinical disciplines in courses with 10 semesters was evidenced from the 3 rd semester, with the highest concentration in the 6th and 7th semesters, comprising 144/253 $(56.9 \%)$ and $139 / 253(54.9 \%)$ of courses. In the 6th semester there was also a higher concentration of the "Clinical Endodontic Discipline" (94/144; 65.3\%) and in the 7 th semester the highest concentration of the "Integrated Clinical Discipline" (107/139; 80\%). Information regarding the distribution of endodontic disciplines of courses lasting 8,9 and 10 semesters is summarized in table 2 .

\section{DISCUSSION}

In the present study, information regarding undergraduate Dentistry courses of Brazilian higher education institutions was analyzed, focusing mainly on the characteristics of clinical endodontic teaching and its curriculum. Few studies have evaluated specific attributes of the profile of Brazilian institutions that offer Dental courses, as well as clinical teaching of endodontics. Thus, it is essential to draw a profile of Brazilian Dentistry courses, as well as the presence of clinical endodontic teaching in the curricula. 
Table 2. Distribution of integrated clinical and endodontic clinical activities over the semesters, considering that in the same course the same clinical discipline may be present in more than one semester

\begin{tabular}{|c|c|c|c|c|c|c|c|c|c|c|c|c|c|c|c|}
\hline \multirow{3}{*}{ 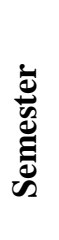 } & \multicolumn{5}{|c|}{8 Semesters $(n=69)$} & \multicolumn{5}{|c|}{9 Semesters $(n=18)$} & \multicolumn{5}{|c|}{10 Semesters $(n=253)$} \\
\hline & \multirow{2}{*}{ ICD } & \multirow{2}{*}{$\begin{array}{c}\text { ICD } \\
+ \\
\text { CED }\end{array}$} & \multirow{2}{*}{ CED } & \multicolumn{2}{|c|}{ Total } & \multirow{2}{*}{ ICD } & \multirow{2}{*}{$\begin{array}{c}\text { ICD } \\
+ \\
\text { CED }\end{array}$} & \multirow{2}{*}{ CED } & \multicolumn{2}{|c|}{ Total } & \multirow{2}{*}{ ICD } & \multirow{2}{*}{$\begin{array}{c}\text { ICD } \\
+ \\
\text { CED }\end{array}$} & \multirow{2}{*}{ CED } & \multicolumn{2}{|c|}{ Total } \\
\hline & & & & $\mathbf{n}$ & $\%$ & & & & $\mathbf{n}$ & $\%$ & & & & $\mathbf{n}$ & $\%$ \\
\hline 1 & 0 & 0 & 0 & 0 & 0 & 0 & 0 & 0 & 0 & 0 & 0 & 0 & 0 & 0 & 0 \\
\hline 2 & 0 & 0 & 0 & 0 & 0 & 0 & 0 & 0 & 0 & 0 & 0 & 0 & 0 & 0 & 0 \\
\hline 3 & 0 & 0 & 0 & 0 & 0 & 0 & 0 & 0 & 0 & 0 & 3 & 0 & 0 & 3 & 1.2 \\
\hline 4 & 1 & 0 & 5 & 6 & 8.7 & 1 & 0 & 1 & 2 & 11.1 & 6 & 3 & 0 & 9 & 3.6 \\
\hline 5 & 4 & 4 & 14 & 18 & 26.1 & 1 & 2 & 4 & 7 & 38.9 & 26 & 7 & 20 & 53 & 20.9 \\
\hline 6 & 7 & 5 & 24 & 36 & 52.2 & 1 & 2 & 11 & 14 & 77.8 & 39 & 11 & 94 & 144 & 56.9 \\
\hline 7 & 22 & 3 & 7 & 32 & 46.4 & 2 & 2 & 6 & 10 & 55.6 & 82 & 25 & 32 & 139 & 54.9 \\
\hline 8 & 25 & 3 & 1 & 29 & 42.0 & 7 & 0 & 0 & 7 & 38.9 & 69 & 20 & 11 & 100 & 39.5 \\
\hline 9 & - & - & - & - & - & 5 & 0 & 0 & 5 & 27.8 & 55 & 12 & 0 & 67 & 26.5 \\
\hline 10 & - & - & - & - & - & - & - & - & - & - & 40 & 8 & 0 & 48 & 19.0 \\
\hline
\end{tabular}

ICD: Integrated clinical discipline; CED: Clinical endodontic discipline

The methods used resulted in a broad and comprehensive sample of Brazilian educational institutions. This sample is substantially larger and broader than those evaluated in previously proposed studies ${ }^{5-8}$. Previous studies were based on secondary data obtained from the website of the Federal Dental Council (CFO). Only the study by Kapler et al. (2019) $)^{5}$ sought information on the electronic websites of educational institutions about their curricula. The limitations of the current study are characterized by the lack of complete information on the websites of researched institutions, especially concerning the description of subjects in their curricula and teaching plans.

In January 2019, there were 452 Dental courses registered on the website of the Brazilian
Ministry of Education, $86.3 \%$ of which are offered in private institutions. In 2007 there were 188 dental courses, being 54 public and 134 private $^{6}$. In 2009, 189 Dental courses were observed in Brazil, mainly concentrated in the Southeast and South ${ }^{8}$. In 2016, 220 courses were identified in Brazil based on secondary data from the CFO, most of them in private institutions ${ }^{7}$. The present study emphasizes that the significant start of new Dental courses in private institutions occurred from the 90's. The opening of new Dental courses was already discussed at the National Oral Health Conferences in 1986 and 1993, and in the Brazilian Association for Dental Education (ABENO), which demonstrates the concern about the teaching of Dentistry and the quality of courses ${ }^{7}$. 
In 2017 , by the Official Letter $1573 / 2017$, reiterated in 2019 by the Official Letter 111/2019, the CFO demonstrates the concern of the category about the large number of Dental courses authorized by MEC and a possible decrease in the quality of care and teaching in higher education institutions. According to the CFO letters, the opening of new courses jeopardizes the sustainability of the profession in the middle and long terms, and the indiscriminate growth of the offer of graduation in Dentistry can interfere with the quality of services offered to the population ${ }^{9,10}$. In addition, the excessive number of courses may jeopardize the quality of education offered ${ }^{11}$.

The pedagogical project consisted of only $23.45 \%$ of the institutions' websites $(17.17 \%$ of private institutions and $62.9 \%$ of public institutions). Elaboration of the pedagogical project should aim at integral and adequate formation of the student by articulation between teaching, research and extension/assistance, besides orienting the curriculum of undergraduate courses in Dentistry to an academic and professional profile of graduates ${ }^{1}$. The importance of their access on electronic sites is unquestionable. The pedagogical project allows to know the structure and development of the course in an institution and provides a comparison of the dynamics of different Dental courses. Thus, it is noteworthy that greater attention is given by educational institutions to the preparation and availability of pedagogical projects of courses offered.

The curriculum was available in $286 / 390$ $(73.3 \%)$ of the websites of courses in private institutions and in 60/62 (96.77\%) of courses of public institutions, totaling $76.5 \%$ of institutions surveyed. This number is much higher than that related to the availability of pedagogical projects in the same sites. This is probably because, according to Haas $(2010)^{12}$, the curricula reveal the proposed training for each course and program, summarizing the pedagogical projects of the courses, and work as a contract signed between students and professors.

Regarding the period in which Dental courses are offered, the daytime period prevailed. Nighttime courses are mostly provided in private educational institutions, while in public institutions this number is still low. The Brazilian reality of working students is that they work during the day while seeking their professional education in the undergraduate course. In 2005, $60.1 \%$ of the total enrollment in higher education in the country involved nighttime courses ${ }^{13}$. It is noteworthy that $55.7 \%$ of students of a nighttime Dentistry course in a federal institution are working ${ }^{14}$, while this fact was reported by $7.1 \%$ of daytime students of the same institution ${ }^{15}$. Public higher education institutions usually offer full-time courses, which does not include the large contingent of working students ${ }^{16}$. Efforts to expand courses at night were made possible by Decree N. 6,096, of April 24, 2007, which established the Program of Support to Restructuring and Expansion of Federal Universities (Programa de Apoio a Planos de Reestruturação e Expansão das Universidades Federais - REUNI) ${ }^{17}$. However, according to the present results, only two new Dental courses started from this period at federal higher education institutions. Thus, it seems that public teaching of Dentistry imposes restrictions on students who would need a night shift.

The average workload of undergraduate Dentistry courses in Brazil is higher than the minimum required by $\mathrm{CNE} / \mathrm{CES}$ Opinion No. $8 / 2007$. Most courses have a duration of 10 semesters, ranging from 8 to 16 . Changes in the length of courses are foreseen in the opinion of CNE/CES No. 8/2007, because the time of payment may change due to the development of courses in special regimens, such as full-time, which must be consistently justified in pedagogical projects $^{18}$. There was only one course with minimum workload of less than 4,000 hours on the 
MEC website. It can be considered that other complimentary activities are offered to academics and are included in the final workload, which were not computed in the amount presented on the website.

There is predominance of clinical teaching of endodontics in integrated Dental clinics, thus revealing a possible establishment of the curriculum advocated by the National Curriculum Guidelines. When offered, the "Clinical Discipline in Endodontics" focuses primarily on the intermediate semesters of the Dental course. The "Integrated Clinical Discipline" has its highest concentration in the final semesters. This analysis is pertinent because it provides data related to the type of clinical training offered to academics. The performance of clinical activities within the undergraduate curriculum is one of the determining aspects for the development of confidence in the practices of Dental students, modulating their selfconfidence $^{19}$. Thus, strategies should be adopted to enable the favorable development of competences associated with the areas of Dental practice.

The results of this study should be considered with caution since the collection of information of interest could have been complete if the sources for analysis were better reported or more accurate. It is well known that clinical endodontics is worked on undergraduate Dentistry courses. However, often this information about insertion in the course is not clearly available. Thus, the elaboration and dissemination of pedagogical projects and curriculum matrices of educational institutions should be included as a mandatory part of their evaluation, both for the opening of new courses and their maintenance. Also, essential aspects of teaching, such as the indispensable content to be addressed and/or practiced in the different disciplines that are inherent and important to the formation of a generalist dentist, in order to enable technical equivalence among graduate professionals, could be incorporated into the NCG.
Understanding how the area of clinical endodontics is inserted in the curricula of undergraduate Dentistry courses allows understanding how the specialty contributes to the generalist, humanistic, critical and reflective training of the Brazilian dentist.

\section{CONCLUSION}

Much information regarding higher education institutions and undergraduate Dentistry courses, their pedagogical project or their curriculum, is not available on the institutions' websites. When present, they are often incomplete, hampering the identification of an adopted didactic model. Dentistry courses preferably take place in private institutions, full-time, with an average duration of 10 semesters, being concentrated mainly in the Southeast region of the country. The teaching of clinical endodontics occurs in an integrated manner with other areas of Dentistry.

\section{RESUMO}

Cursos de Odontologia e a Endodontia Clínica em Instituições de Ensino Superior Brasileiras Este estudo transversal do tipo censo avaliou características dos cursos e os modelos de ensino de endodontia clínica nos cursos de Odontologia no Brasil. Realizou-se acesso a sítios eletrônicos de 452 cursos registrados no Cadastro Nacional de Cursos e Instituições de Educação Superior do Ministério da Educação. As variáveis de interesse foram: dados da instituição; presença de matriz curricular e projeto pedagógico do curso: dados do curso (número de semestres, turno de realização), dados referentes à área de endodontia clínica. Os dados foram inseridos em banco de dados e foi realizada análise estatística descritiva. A graduação em Odontologia ocorre majoritariamente em instituições privadas $(86,3 \%)$ e na região sudeste $(37,8 \%)$, sendo os cursos em sua maioria diurnos $(73,8 \%)$. A matriz curricular e os projetos pedagógicos estavam disponíveis em 76,5\% e $23,4 \%$, respectivamente, sendo predominantemente encontrados nos sítios eletrônicos de instituições públicas. $\mathrm{O}$ ensino de endodontia clínica tem início 
em diferentes momentos, conforme o curso, iniciando no terceiro semestre e pode ocorrer de forma isolada ou em clínica integrada. Conclui-se que há um predomínio de oferta de ensino de graduação em Odontologia em instituições privadas. Há um número restrito de vagas em cursos noturnos. Há uma tendência que o ensino de endodontia clínica ocorra de forma integrada com as demais áreas da Odontologia. A coleta de informações é dificultada pelo número restrito de projetos pedagógicos disponíveis para consulta. O total acesso a estar informações permitiria que o aluno, ao ingressar na instituição, conheça como ocorrerá o processo de ensino-aprendizagem.

Descritores: Endodontia. Ensino. Currículo.

\section{REFERENCES}

1. Brasil. Conselho Nacional de Educação. Câmara de Educação Superior. Resolução CNE/CES 3/2002, de 19 de fevereiro de 2002. Institui as Diretrizes Curriculares Nacionais do Curso de Graduação em Odontologia. Seç. 1 mar 4, 2002.

2. Prats, LD. Disciplina de Endodontia: uma análise a partir da ótica de docentes e discentes de odontologia [tese]. São Paulo: Universidade Federal de São Paulo; 2005.

3. de Moor R, Hülsmann M, Kirkevang L-L, Tanalp J, Whitworth J. Undergraduate curriculum guidelines for endodontology. Int Endod J. 2013;46(12):1105-14

4. American Association of Endodontists. Guide to Clinical Endodontics. 6th ed. 2013. [Cited May 14, 2019]. Available at: https://www.aae.org/specialty/clinical-resou rces/guide-clinical-endodontics/

5. Kapler RB, de Paula KB, Barbisan DB, Grock CH, Ferreira MBC, Luisi SB. Preclinical Endodontics teaching in Brazilian Dentistry courses. Rev ABENO. 2019; 19(2): 82-90.

6. Lucietto DA, Amâncio Filho A, Oliveria SP. Revisão e discussão sobre indicadores para a previsão de demanda por cirurgiões- dentistas no Brasil. Rev Fac Odontol Porto Alegre. 2008; 49(3): 28-35.

7. Martin ASS, Chisini LA, Martelli S, Sartori LRM, Ramos EC, Demarco FF. Distribuição dos cursos de Odontologia e de cirurgiõesdentistas no Brasil: uma visão do mercado de trabalho. Rev ABENO. 2018; 18(1): 63-73.

8. Paranhos L, Ricci I, Scanavini M, Bérzin F, Ramos A. Análise do mercado de trabalho odontológico na região Sul do Brasil. RFO UPF. 2009; 14(1): 7-13.

9. Conselho Federal de Odontologia. Ofício CFO 1573/2017 de novembro de 2017. Suspensão de novos cursos de odontologia. Brasília, DF. [Cited May 15, 2019]. Available at: http://cfo.org.br/website/cfopede-a-ministro-da-educacao-que-nao-auto rize-novos-cursos-de-odontologia-no-pais/

10. Conselho Federal de Odontologia. Ofício CFO 111/2019 de janeiro de 2019. Suspensão de novos cursos de odontologia. Brasília, DF. [Cited May 15, 2019]. Available at: http://cfo.org.br/website/cforeforca-necessidade-do-ministerio-da-educa cao-suspender-autorizacoes-para-aberturade-novos-cursos-de-odontologia/

11. Jeunon FA, Santiago MO. A Formação de recursos humanos e o mercado de trabalho em Odontologia. Rev CROMG. 1999; 5(2): 79-94.

12. Haas CM. Projetos pedagógicos nas instituições de educação superior: aspectos legais na gestão acadêmica. RBPAE. 2010; 26(1): 151-71.

13. Terribili Filho A. Ensino superior noturno no Brasil: estudar para trabalhar ou trabalhar para estudar? Pensamento e Realidade. 2008; 11(22): 43-65.

14. Souza, JM, Weschenfelder HC, Toassi RFC. Expansão da educação superior no Brasil a partir do REUNI: o curso noturno de odontologia da Universidade Federal do Rio 
Grande do Sul. GUAL. 2014; 7(1): 63-78.

15. Toassi RFC, Souza JM, Rösing CK, Baumgarten A. Perfil sociodemográfico e perspectivas em relação à profissão do estudante de odontologia da Universidade Federal do Rio Grande do Sul, Brasil. Rev Fac Odontol Porto Alegre. 2011; 52(1): 2532.

16. Vargas H, Paula M. A inclusão do estudantetrabalhador e do trabalhador-estudante na educação superior: desafio público a ser enfrentado. Avaliação (Campinas). 2013; 18(2): 459-85.

17. Brasil. Decreto ${ }^{\circ} 6.096$, de 24 de abril de 2007. Institui o Programa de Apoio a Planos de Reestruturação e Expansão das Universidades Federais: REUNI. Brasília, DF. [Cited May 15, 2019]. Available at: http://www.planalto.gov.br/ccivil_03/_Ato2 007-2010/2007/Decreto/D6096.htm
18. Brasil. Parecer CNE/CES nº/2007, de 31 de janeiro de 2007. Dispõe sobre carga horária mínima e procedimentos relativos à integralização e duração dos cursos de graduação, bacharelados, na modalidade presencial. Conselho Nacional de Educação. Câmara de Educação Superior. Brasília, DF. [Cited May 15, 2019]. Available at: http://portal.mec.gov.br/cne/arquivos/pdf/2 007/pces008_07.pdf

19. Murray FJ, Blinkhorn AS, Bulman J. An assessment of the views held by recent graduates on their undergraduate course. Eur J Dent Educ. 1999; 3(1): 3-9.

\section{Correspondence to:}

Prof Dr Francisco Montagner

e-mail: francisco.montagner@ufrgs.br

Universidade Federal do Rio Grande do Sul

Faculdade de Odontologia

Rua Ramiro Barcelos, 2492

90035-003 Porto Alegre/RS Brazil 